\title{
Dyslipidemias and obesity in Mexico
}

\author{
Simón Barquera, MD, MS, PhD,(1) Mario Flores, MD, MS,(1) Gustavo Olaiz-Fernández, MD, MSP, \\ Eric Monterrubio, MS, (I) Salvador Villalpando, MD, PhD, (l) Carlos González, MD,(I) \\ Juan Ángel Rivera, MS, PhD, (I) Jaime Sepúlveda, MC, M en C, D en C.(I)
}

\section{Barquera S, Flores M, Olaiz-Fernández G, Monterrubio E, Villalpando S, González C, Rivera J, Sepúlveda J. Dyslipidemias and obesity in Mexico.} Salud Publica Mex 2007;49 suppl 3:S338-S347.

\begin{abstract}
Objective.To describe in a national sample I) the mean total cholesterol (TC), HDL-cholesterol (HDLc) and triglyceride (TG) concentrations, 2) the prevalence of the most common lipid abnormalities and 3) the association between obesity and these conditions. Material and Methods. We analyzed the nationally representative, cross-sectional Mexican Health Survey (2000). The final analytic sample used consisted of $235 \mathrm{I}$ individuals at fasting state. TC, HDLc and TG were determined. BMI was classified according to the WHO cutoff points. Sex-specific means and $95 \%$ confidence intervals $(95 \% \mathrm{Cl})$ were calculated by age group for TC, HDLc and TG. The prevalence of: a) hypercholesterolemia $(\mathrm{HC}), \mathrm{b})$ hypoalphalipoproteinemia (HA), c) hypertriglyceridemia (HT), d) HT with HA and e) HC with HT was calculated adjusting for age. Multivariate logistic regression models were estimated to analyze the association of obesity to the prevalence of dyslipidemias. Results. The mean TC, HDLc, and TG concentrations were: $197.5 \mathrm{mg} / \mathrm{dl}(95 \% \mathrm{Cl}=194.0$, $20 \mathrm{l} . \mathrm{I}), 38.4 \mathrm{mg} / \mathrm{dl}(95 \% \mathrm{Cl}=37.2,39.5)$ and $181.7 \mathrm{mg} / \mathrm{dl}(95 \%$ $\mathrm{Cl}=172.7,190.6)$, respectively. $\mathrm{HC}$ was present in $40.5 \%$ of the adult females $(95 \% \mathrm{Cl}=35.5,45.4)$ and 44.6 of the adult males (95\% Cl=37.7, 5I.4); $\mathrm{HA}$ was the most prevalent form of dyslipidemia, present in $64.7 \%(95 \% \mathrm{Cl}=58.7,70.8)$ and $61.4 \%(95 \% \mathrm{Cl}=54.4,68.3)$ of females and males, respectively. Obesity increased $\sim 1.4$ times the probability ratio (PR) of having $\mathrm{HC}$ among women and I.9 among men. Conclusion. TC concentrations from our study in Mexico were similar to those found for Mexican-Americans and the prevalence of $\mathrm{HC}$ was slightly lower than the one reported in the US;
\end{abstract}

Barquera S, Flores M, Olaiz-Fernández G, Monterrubio E, Villalpando S, González C, Rivera J, Sepúlveda J.

Dyslipidemias and obesity in Mexico.

Salud Publica Mex 2007;49 supl 3:S338-S347.

\section{Resumen}

Objetivo. Describir en una muestra nacional las concentraciones de I) colesterol total (CT), colesterol-HDL (cHDL) y triglicéridos, 2) la prevalencia de las anomalías lipídicas más comunes y 3) identificar la asociación entre obesidad y estas condiciones. Material y métodos. Se analizó la Encuesta Nacional de Salud (2000), una encuesta representativa y transversal. La muestra analítica final consistió en $235 \mathrm{I}$ individuos en ayuno. Se determinaron las concentraciones de CT, cHDL y TG. El índice de masa corporal se clasificó de acuerdo con los puntos de corte de la OMS. Se calcularon las medias y el intervalo de confianza del $95 \%$ (IC95\%) estratificado por sexo para CT, cHDL yTG. La prevalencia de a) hipercolesterolemia $(\mathrm{HC}), \mathrm{b})$ hipoalfalipoproteinemia $(\mathrm{HA}), \mathrm{c})$ hipertrigliceridemia (HT), d) HT con HA y e) HC con HT se calculó ajustando por edad. Se estimaron modelos de regresión logística multivariada para analizar la asociación de la obesidad a la prevalencia de dislipidemias. Resultados. Las medias de CT, cHDL y TG fueron: $197.5 \mathrm{mg} / \mathrm{dl}$ (IC95\%= 194.0, 20I.I), 38.4 $\mathrm{mg} / \mathrm{dl}($ IC95\%= 37.2,39.5) y $\mathrm{l} 8 \mathrm{I} .7 \mathrm{mg} / \mathrm{dl}$ (IC95\%= I72.7, 190.6) respectivamente. La prevalencia de $\mathrm{HC}$ fue de $40.5 \%$ en mujeres $(I C 95 \%=35.5,45.4)$ y 44.6 en hombres (IC95\%=37.7,5I.4); HA fue la forma más prevalente de dislipidemia, presente en $64.7 \%(I C 95 \%=58.7,70.8)$ y $61.4 \%(I C 95 \%=54.4,68.3)$ de las mujeres y los hombres respectivamente. La obesidad aumentó $\sim 1.4$ veces la razón de probabilidad de tener $\mathrm{HC}$ en mujeres y 1.9 en hombres. Conclusión. Las concentraciones de CT de nuestro estudio fueron similares a las encontradas en mexicanos residentes en los EUA y la prevalencia de $\mathrm{HC}$ fue ligeramente menor que la reportada en dicho país; sin

(I) Instituto Nacional de Salud Pública. México.

(2) Secretaría de Salud. México.

Received on: February 2, 2006 - Accepted on: October 20, 2006

Address reprint requests to: PhD. Simón Barquera. Instituto Nacional de Salud Pública.Av. Universidad 655, Col. Santa María Ahuacatitlán. 62508 Cuernavaca, Morelos, México.

E-mail:sbarquera@insp.mx 
however, it increased $26 \%$ from 1988 to 2000 . HA was the most frequent lipid abnormality followed by HT. Regions showed no significant differences, contrary to what has been previously reported.

Keywords: triglycerides; HDL-cholesterol; central adiposity; overweight; national surveys; Mexico embargo aumentó $26 \%$ de 1988 a 2000. Las HA fueron la anomalía lipídica más frecuente seguida de HT. Las regiones no mostraron diferencias significativas, contrario a lo que se había reportado previamente.

Palabras clave: triglicéridos; colesterol HDL; adiposidad central; sobrepeso; encuestas nacionales; México
$\mathbf{M}_{\mathrm{p}}$ exico is a middle-income country which has experienced in the last decades a significant shift in socio-economic conditions and urbanization, with an impact on diet and sedentary life styles. These changes have been associated with the epidemiologic transition currently experienced in diverse developing countries, characterized by high prevalences of obesity and nutrition-related, non-communicable chronic diseases (NCCDs). ${ }^{1,2}$ The development of a national system of health surveys has allowed the identification of diverse public health problems in Mexico, such as nutritionrelated NCCDs. In order to face the resulting rapid rise in mortality, the National Health Plan (2001-2006) is addressing for the first time, explicitly as health priorities, diverse emerging diseases such as obesity, diabetes, high blood pressure and dyslipidemias. ${ }^{3}$

Hypercholesterolemia and other blood lipid abnormalities are major modifiable risk factors for coronary heart disease (CHD), ${ }^{4-6}$ and represent the second cause of general mortality in the country with $10.8 \%$ of allcause mortality (2003). ${ }^{7}$ However, the characteristics of hypercholesterolemia in Mexico have only been described at the national level recently. ${ }^{8-11}$ The National Seroepidemiologic Survey (1988) reported higher cholesterol levels and prevalences of hypercholesterolemia between the more developed north and the less developed south country regions. On average, it was found that Mexico had lower mean total cholesterol concentrations than populations from the US and Europe; however, these concentrations were similar to those of subjects from the north country region. ${ }^{9}$ High-density lipoprotein cholesterol (HDLc) was not determined in that survey, but a study in urban population of Mexico City reported low mean concentrations. ${ }^{12}$ The National Chronic Diseases Survey (1994) provided information about HDLc and other lipid abnormalities in urban areas of the country. ${ }^{10,13}$ Using this survey, Aguilar-Salinas et al, found that low HDLc $(<0.9 \mathrm{mmol} / \mathrm{L}[<35 \mathrm{mg} / \mathrm{dl}])$ concentrations was the most prevalent lipid abnormality (46.2\% in men and $28.7 \%$ in women). This study compared the mean lipid concentrations with results from other populations, finding that urban Mexicans had the higher values for triglycerides and the lowest for HDLc.

The objective of this study is to describe in a national sample a) the mean total cholesterol, HDL-cholesterol and triglycerides concentrations, $b$ ) the prevalence of the most common lipid abnormalities stratified by sex, age, area and region, as well as c) to identify the association between body mass index and central adiposity with these conditions.

\section{Material and Methods}

The present study used data from the nationally representative, cross-sectional Mexican Health Survey (MHS), implemented in $2000 .{ }^{14} \mathrm{~A}$ multi-stage sampling procedure was used. A detailed description of the sampling design and methods is available in this supplement. ${ }^{15}$ From the primary sampling units, a total of 45726 households were selected, which included 24856 men and 26747 women over the age of twenty years from urban and rural areas. A structured questionnaire was used to obtain socio-demographic data, family history, clinical symptoms, and medical treatment for various chronic diseases. A single blood sample was drawn by trained personnel from approximately 44000 cases and the serum was frozen at $-150^{\circ} \mathrm{C}$ degrees until analysis. For the purpose of this study, all individuals who had a 9- to 12-h fasting period at the moment of the blood collection were selected ( $n=2478$ ). Diverse biochemical parameters were measured in these subjects. The final analytic sample for blood lipids consisted of 2351 individuals. There were no statistically significant differences between fasting (FA) and non-fasting (NFA) cases for the following individual and socio-demographic variables: sex, education, location, and region. Small differences were found in age $(\mathrm{FA}=38.9 \pm 15.6$ years, $\mathrm{NFA}=41.8 \pm 16.2$ years), weight $(F A=66.9 \pm 14.7 \mathrm{~kg}, \mathrm{NFA}=67.7 \pm 15.1 \mathrm{~kg})$, and height $(\mathrm{FA}=157.5 \pm 9.6 \mathrm{~cm}, \mathrm{NFA}=156.7 \pm 9.4 \mathrm{~cm})$. Blood pressure was similar between the fasting and nonfasting cases $(\mathrm{FA}=$ systolic $=121 \pm 0.6$, diastolic $=80 \pm 0.5$ 
$\mathrm{mmHg}),(\mathrm{NFA}=123 \pm 0.1$, diastolic $=80.0 \pm 0.1)$. The prevalence of high blood pressure was higher in NFA (34.9\%) than in FA $(31 \%, p<0.01)$. The prevalence of medical diagnosis of hypercholesterolemia was similar between the groups (NFA $=7.6 \%, \mathrm{FA}=6.5 \%, \mathrm{p}=0.06$ ).

Consent for participation was obtained from all participants. The project was approved by the scientific and ethics committees of the National Institute of Public Health. In addition, data collection was implemented considering the confidentiality and reserve rights stipulated by the Mexican Statistical and Geographic information law. ${ }^{16}$

\section{Cholesterol and dyslipidemias}

The blood samples of fasting individuals were analyzed to determine serum total cholesterol, high-density cholesterol (HDLc) and triglycerides using a semi-automatic spectrophotometer (Prestige 241- Boeki Medical Systems LTD, Tokyo, Japan) in our Nutrition and Metabolism laboratory at the National Institute of Public Health. Hypercholesterolemia was defined as a serum concentration $\geq 200 \mathrm{mg} / \mathrm{dl}$ (5.2 mmol/L), hypoalphalipoproteinemia was defined as a HDL cholesterol (HDLc) concentration $<40 \mathrm{mg} / \mathrm{dl}(1.0 \mathrm{mmol} / \mathrm{L})$, hypertriglyceridemia was defined as a serum concentration $\geq 150 \mathrm{mg} / \mathrm{dl}(1.7$ $\mathrm{mmol} / \mathrm{L}){ }^{17}$ In addition, the prevalence of the following dyslipidemias is described: Hypertriglyceridemia with hypoalphalipoproteinemia, defined as triglycerides $\geq 200 \mathrm{mg} / \mathrm{dl}(2.26 \mathrm{mmol} / \mathrm{L})$ and HDL cholesterol <35 $\mathrm{mg} / \mathrm{dl}(0.9 \mathrm{mmol} / \mathrm{L})$ and mixed dyslipidemias, defined as triglycerides $\geq 200 \mathrm{mg} / \mathrm{dl}(2.26 \mathrm{mmol} / \mathrm{L})$ and cholesterol $\geq 240 \mathrm{mg} / \mathrm{dl}(6.31 \mathrm{mmol} / \mathrm{L}){ }^{10}$

\section{Anthropometric variables}

Following internationally accepted techniques, standardized personnel measured height to the nearest $0.1 \mathrm{~cm}$, using a stadiometer (model 202, Seca Ltd, Birmingham, UK) and weight using a digital scale (1631 solar scale, Tanita Corp, Tokyo, Japan) with an error of $5 \mathrm{~mm}$ and $0.1 \mathrm{~kg}$, respectively. Waist circumference (WC) was measured at the mid point between the highest part of the iliac crest and the lowest part of the ribs margin of the median axial line. The body mass index (BMI) was calculated by dividing the weight in kilograms by the height in $\mathrm{m}^{2}$ and categorized according to the World Health Organization (WHO) cut-off points into: normal weight $\left(18.5-24.9 \mathrm{~kg} / \mathrm{m}^{2}\right)$, overweight $\left(25-29.9 \mathrm{~kg} / \mathrm{m}^{2}\right)$ and obesity $\left(\geq 30 \mathrm{~kg} / \mathrm{m}^{2}\right) ;{ }^{18}$ if WC was $\geq 102 \mathrm{~cm}$ in males or $\geq 88 \mathrm{~cm}$ in females the subject was classified as having abdominal adiposity based on the National Institutes of Health guidelines. ${ }^{17}$

\section{Geographic regions}

The regions were defined as follows: North region (Baja California, Southern Baja California, Coahuila, Durango, Nuevo Leon, Sonora, Sinaloa, Tamaulipas and Zacatecas), Central region (Aguascalientes, Colima, Guanajuato, Hidalgo, Jalisco, Mexico, Michoacan, Nayarit, Queretaro, San Luis Potosi and Tlaxcala), Metropolitan area of Mexico City and South Region (Campeche, Chiapas, Guerrero, Morelos, Oaxaca, Puebla, Quintana Roo, Tabasco, Veracruz and Yucatan). This regionalization scheme has been used in many epidemiologic transition analyses for within country comparisons. ${ }^{19,20}$ The North region is highly industrialized and productive, with lower unemployment rates than the rest of the country. This region has also a close cultural and economic relationship with the southern border of the US. The Central region is less developed than the North but includes some major cities such as Guadalajara. Mexico City is highly urbanized, and the most heterogeneous country region with approximately 20 million inhabitants; it has high immigration from the southern states and poverty pockets, together with good access to many types of subsidies and basic services. Finally, the South region is less developed, with higher poverty rates, maternal and child undernutrition, the highest rates of infant mortality and the highest proportion of indigenous inhabitants.

\section{Statistical analysis}

Due to the characteristics of the survey design, in the present study the estimates were calculated controlling for intra-cluster correlation using STATA 8.2 (College Station, TX, USA). ${ }^{*}$ First, a descriptive analysis of the population characteristics was conducted. Sex-specific means and $95 \%$ confidence intervals $(95 \% \mathrm{CI})$ were calculated by age group for total cholesterol, HDLc and triglycerides. In a second step, age-adjusted, sex-specific means were estimated stratifying by: BMI, abdominal obesity, region and area.

The sex-specific prevalence and 95\% CI of: a) hypercholesterolemia, b) hipoalhpalipoproteinemia, c) hypertriglyceridemia, d) hypertriglyceridemia with hypoalphalipoproteinemia and e) mixed dyslipidemias were calculated first by age group and subsequently by region and area, adjusting for age. Next, five non-conditional multivariate logistic regression models were

\footnotetext{
* Stata Corp. Stata reference manual. Release 7. College Station, TX, USA: Stata Press, 2001.
} 
estimated to analyze by sex, the contribution of BMI category (normal, overweight and obese) or abdominal adiposity as the main independent variables, to the prevalence of the five previously defined dyslipidemias. Other explored variables included in the models as potential confounders include: age, familiar history of dyslipidemias; country region; previously diagnosed hypercholesterolemia and tobacco consumption (number of cigarettes smoked/ day). Only those variables that had values higher than $p<0.25$ in the bivariate analysis were included. Control variables significant or marginally significant $(p<0.09)$ were kept in the final models. Interactions that were important from a theoretical point of view such as BMI category and abdominal adiposity by region were tested, however, no interaction was significant at a $p<0.15$ level. The model's adjustment was carried out using maximum likelihood estimates and considering a p-value cutoff point of $>0.10$ which indicated an appropriate adjustment. Probability ratios were estimated from odds ratios using the method proposed by Zhang. ${ }^{21,22}$ As a final step we calculated the probabilities of having hypercholesterolemia, hypoalphalipoproteinemia and hypertriglyceridemia and any possible combination of these abnormalities in the analytic sample and in the obese and normal groups, and represented the obtained coefficients of normal and obese subjects in two area-proportional Venn diagrams to visually convey information about their interacting characteristics. ${ }^{23}$

\section{Results}

Our study included 2351 adults $\geq 20$-y of age from the Mexican National Health Survey (2000) who where at fasting during the interview. The mean total cholesterol (TC), HDLc, and triglycerides (TG) concentrations were: $197.5 \mathrm{mg} / \mathrm{dl}(95 \% \mathrm{CI}=194.0,201.1), 38.4 \mathrm{mg} / \mathrm{dl}(95 \% \mathrm{CI}=$ $37.2,39.5)$ and $181.7 \mathrm{mg} / \mathrm{dl}(95 \% \mathrm{CI}=172.7,190.6)$ respectively. A total of $38.2 \%$ of the population were overweight (37.6\% females, 38.8\% males) and $21.1 \%$ were obese (26.5\% females, $16.0 \%$ males). Abdominal obesity was present in $38.2 \%$ of the cases ( $58.0 \%$ females, $19.6 \%$ males).

Table I shows the mean cholesterol, HDLc and triglycerides concentrations by age group. Adults 20-29-y of age had significantly lower TC and TG concentrations compared to adults $>29-y$ of age. HDLc showed no statistically significant differences by age group. Males had significantly higher TG concentrations than females (199 vs $163 \mathrm{mg} / \mathrm{dl} p<0.05$ ), but no statistically significant differences were found by sex for TC and HDLc. Less than $7 \%$ of our population had been previously diagnosed with hypercholesterolemia. Mean TC,
HDLc and TG concentrations were estimated by BMI category, abdominal obesity category, region and area, finding only a few statistically significant differences after adjusting by age (Table II). Females with abdominal obesity had higher TC (200 vs $187 \mathrm{mg} / \mathrm{dl}, p<0.05)$ and TG (179 vs $135 \mathrm{mg} / \mathrm{dl}, p<0.05)$ than those without it, but showed no significant difference by BMI category. Males showed lower concentrations of TC and TG in normal BMI adults compared to overweight and obese but no significant differences were observed for HDLc. In this group, abdominal obesity was only associated to higher concentrations of triglycerides (253 vs 190 $\mathrm{mg} / \mathrm{dl}, p<0.05)$. No statistically significant differences were found by region or area for males or females with the exception of TC in males, which was higher in the central region than in the south region (206 vs $187 \mathrm{mg} / \mathrm{dl}$, $p<0.05$ ).

Prevalences of the five previously described dyslipidemias are presented stratified by sex, age, region and area in table III. Hypercholesterolemia (TC $>200 \mathrm{mg} / \mathrm{dl}$ ) was present in $40.5 \%$ of the adult females $(95 \% \mathrm{CI}=35.5$, $45.4)$ and 44.6 of the adult males $(95 \% \mathrm{CI}=37.7,51.4)$; hypoalphalipoproteinemia (HDLc $<40 \mathrm{mg} / \mathrm{dl}$ ) was the most prevalent form of dyslipidemia, present in $64.7 \%$ $(95 \% \mathrm{CI}=58.7,70.8)$ and $61.4 \%(95 \% \mathrm{CI}=54.4,68.3)$ of females and males, respectively. Hypertriglyceridemia with hypoalphalipoproteinemia and mixed dyslipidemias were significantly more prevalent in males than in females.

Table IV shows the prevalence ratios (PR) of having a dyslipidemia by BMI or abdominal adiposity stratifying by sex and adjusting for age and other previously mentioned confounders. In females, obesity and abdominal obesity increased $\sim 1.4$ the PR of having hypercholesterolemia, but overweight was not significantly associated. In males, overweight increased 1.5 the PR and obesity increased it by 1.93 , but abdominal obesity did not increase significantly the adjusted PR of having hypercholesterolemia. Hypoalphalipoproteinemias were not associated to BMI category or abdominal obesity in males or females. Hypertriglyceridemia was associated to both obesity category and abdominal obesity in males and females. Hypertriglyceridemia with hypoalphalipoproteinemia had no significant associations with the adiposity indicators in females and males. Mixed dyslipidemias increased with BMI category and had a significant test for trend in males but not in females. Obese males were 5.25 times more likely to have mixed dyslipidemias than normal males (95\% CI= 2.48, 9.42). The age and sex-adjusted probabilities of having more than one lipid abnormality in obese Mexican adults compared to those of normal BMI is illustrated in Figure 1 with Venn diagrams for (a) cases classified as normal and 
Table I

Concentrations of Cholesterol, HDL-cholesterol and triglycerides in Mexican adults*. Mexican Health Survey, 2000

\begin{tabular}{llll}
$\begin{array}{l}\text { Age group } \\
\text { (years) }\end{array}$ & $\begin{array}{c}\text { Both sexes }(n=2,35 I) \\
\text { Mean }(95 \% \mathrm{Cl})\end{array}$ & $\begin{array}{c}\text { Females }(\mathrm{n}=1,552) \\
\text { Mean }(95 \% \mathrm{Cl})\end{array}$ & $\begin{array}{c}\text { Males }(\mathrm{n}=799) \\
\text { Mean }(95 \% \mathrm{Cl})\end{array}$ \\
$\begin{array}{l}\text { Cholesterol }(\mathrm{mg} / \mathrm{dl})^{\ddagger} \\
20-29\end{array}$ & $184.0(178.6,189.4)$ & $181.1(175.9,186.2)$ & $186.6(177.8,195.5)$ \\
\hline $30-39$ & $201.2(195.4,206.9)$ & $195.7(188.5,202.8)$ & $206.7(197.3,216.0)$ \\
\hline $40-49$ & $214.7(208.5,220.9)$ & $210.7(203.7,217.7)$ & $218.7(207.5,229.9)$ \\
\hline $50-59$ & $216.8(207.7,225.9)$ & $223.4(210.7,236.1)$ & $210.6(198.6,222.7)$ \\
\hline$\geq 60$ & $212.7(202.9,222.5)$ & $222.4(206.5,238.3)$ & $203.9(193.0,214.8)$ \\
\hline Total $(\geq 20)$ & $197.5(194.0,201.1)$ & $196.2(191.7,200.7)$ & $198.8(193.1,204.5)$
\end{tabular}

HDL-cholesterol $(\mathrm{mg} / \mathrm{dl})^{\ddagger}$

\begin{tabular}{|c|c|c|c|c|c|c|}
\hline $20-29$ & 35.8 & $(34.2,37.4)$ & 35.8 & $(33.9,37.8)$ & 35.8 & $(33.5,38.1)$ \\
\hline $30-39$ & 39.7 & $(37.8,41.5)$ & 39.3 & $(37.1,4 \mid .5)$ & 40.0 & $(37.2,42.9)$ \\
\hline $40-49$ & 40.7 & $(38.8,42.7)$ & 40.1 & $(38.2,42.0)$ & 41.4 & $(38.2,44.6)$ \\
\hline $50-59$ & 41.6 & $(39.7,43.5)$ & 43.0 & $(40.5,45.6)$ & 40.3 & $(37.5,43.1)$ \\
\hline$\geq 60$ & 41.2 & $(39.2,43.2)$ & 43.5 & $(40.8,46.2)$ & 39.1 & $(36.3,41.8)$ \\
\hline Total $(\geq 20)$ & 38.4 & $(37.2,39.5)$ & 38.6 & $(37.2,40.0)$ & 38.1 & $(36.4,39.9)$ \\
\hline
\end{tabular}

Triglycerides $(\mathrm{mg} / \mathrm{dl})^{\S}$

\begin{tabular}{|c|c|c|c|}
\hline $20-29$ & I44.6 (I33.8, I55.4) & $13 \mid .5(|19.3| 43.7)$, & $156.3(139.5,173.0)$ \\
\hline $30-39$ & $210.5(190.3,230.8)$ & $175.3(155.3,195.3)$ & $245.7(210.8,280.7)$ \\
\hline $40-49$ & $208.9(182.4,235.5)$ & $177.4(158.6,196.2)$ & $240.5(192.2,288.8)$ \\
\hline $50-59$ & $243.7(202.5,284.9)$ & $236.4(184.4,288.4)$ & $250.4(|87.9,3| 3.0)$ \\
\hline$\geq 60$ & $211.1 \quad(183.1,239.2)$ & $212.9(184.9,240.9)$ & $209.5(172.1,246.9)$ \\
\hline \multirow[t]{2}{*}{ Total $(\geq 20)$} & $181.7(172.7,190.6)$ & $162.9(|54.3,17| .6)$ & $199.5(184.0,214.9)$ \\
\hline & $\%$ & $\%$ & $\%$ \\
\hline edical diagnosis of hypercholesterolemia & 6.1 $\quad(4.5,7.6)$ & $6.7 \quad(4.8,8.6)$ & $(3.4,7.5)$ \\
\hline
\end{tabular}

* Adults were in a 9 - to I2-h fasting state. Estimates and $95 \%$ Confidence Intervals $(95 \% \mathrm{Cl})$ were adjusted for the complex survey design

₹ To convert to $\mathrm{mmol} / \mathrm{L}$ divide by 38.67

$\S$ To convert to $\mathrm{mmol} / \mathrm{L}$ divide by 88.57

(b) those with obesity. The probabilities of co-existence of hypercholesterolemia, hypoalphalipoproteinemia, and hypertriglyceridemia are represented by the primary circles (1, 2, 3 respectively), and the combinations of these conditions are represented by the overlap areas within the circles. This figure shows that hypoalphalipoproteinemia is the dyslipidemia with the highest probability of occurrence in Mexicans. Adults with obesity had higher probability coefficients for most of the combinations of lipid abnormalities.

\section{Discussion}

This study shows the mean concentrations of total cholesterol (TC), HDL cholesterol (HDLc) and triglyc- erides (TG), as well as their association with overweight and obesity as BMI categories, and with abdominal adiposity in the sample of fasting adults from the MHS (2000). Cholesterol concentrations from our study in Mexico are remarkably similar to those found for Mexican-Americans participating in NHANES, ${ }^{24}$ and the prevalence of hypercholesterolemia is slightly lower than the reported average in the US. ${ }^{25}$ However, whether continued increase in cholesterol concentrations will occur in Mexico is not clear, but may be likely to occur, given the observed trend where hypercholesterolemia increased $\sim 5 \%$ from $1988^{11}$ to 1994 and 21\% from $1994^{10}$ to 2000 (this study). Recently, we documented a $29 \%$ increase in fat intake as percentage of total calories in the country, from 1988 to $1999 .{ }^{26}$ This is a relevant 
Table II

\section{Concentrations of Cholesterol, HDL-Cholesterol and triglycerides in Mexican adults BY BODY MASS INDEX AND ABDOMINAL OBESITY CATEGORY*}

\begin{tabular}{|c|c|c|c|c|}
\hline & & $\begin{array}{l}\text { Cholesterol }(\mathrm{mg} / \mathrm{dll})^{\ddagger} \\
\text { Mean }(95 \% \mathrm{Cl})^{\&}\end{array}$ & $\begin{array}{l}\text { HDL-C } C^{\#}(\mathrm{mg} / \mathrm{dll})^{\ddagger} \\
\text { Mean }(95 \% \mathrm{Cl})^{\&}\end{array}$ & $\begin{array}{c}\text { Triglycerides }(\mathrm{mg} / \mathrm{dll})^{\S} \\
\text { Mean }(95 \% \mathrm{Cl})^{\&}\end{array}$ \\
\hline \multicolumn{5}{|l|}{ Females } \\
\hline \multirow[t]{3}{*}{ Body Mass Index } & Normal & $192.6(186.5,198.7)$ & $39.2(37.1,41.4)$ & $147.3(129.5,165.1)$ \\
\hline & Overweight & $195.3(189.8,200.8)$ & $38.2(36.7,39.6)$ & $168.2(154.9,181.6)$ \\
\hline & Obese & $202.8(196.6,209.0)$ & $38.4(36.5,40.2)$ & $183.7(166.9,200.4)$ \\
\hline \multirow[t]{2}{*}{ Abdominal Obesity ${ }^{\infty}$} & No & I86.5 (|80.7,192.3) & $37.5(35.4,39.6)$ & $135.0(121.2,148.8)$ \\
\hline & Yes & $199.9(195.5,204.3)$ & $38.2(37.0,39.5)$ & $178.8(165.3,192.3)$ \\
\hline \multirow[t]{4}{*}{ Region } & North & $193.3(\mid 82.4,204.3)$ & $36.4(33.3,39.6)$ & $147.7(130.3,165.2)$ \\
\hline & Central & $198.6(194.0,203.1)$ & $40.0(38.2,41.9)$ & $163.1 \quad(151.9,174.3)$ \\
\hline & Mexico city & $202.3(|8| .2,223.4)$ & $34.8(28.4,41.3)$ & $139.9(124.4,155.5)$ \\
\hline & South & $187.9(\mid 82.1,193.8)$ & $36.4(34.4,38.4)$ & $165.3(147.8,182.7)$ \\
\hline \multirow[t]{2}{*}{ Area } & Rural & $193.3(188.4,198.1)$ & $37.9(36.6,39.3)$ & $164.7(\mid 53.1,176.2)$ \\
\hline & Urban & $196.2(191.3,201.2)$ & $38.7(36.5,40.9)$ & $159.5(|47.2| 7 \mid .8)$, \\
\hline \multicolumn{5}{|l|}{ Males } \\
\hline \multirow[t]{3}{*}{ Body Mass Index } & Normal & $189.4(\mid 82.5,196.2)$ & $37.5(35.3,39.7)$ & $165.1 \quad(\mid 44.1,186.0)$ \\
\hline & Overweight & $206.7(197.4,216.0)$ & $38.8(36.3,41.3)$ & $219.8(193.4,246.3)$ \\
\hline & Obese & $217.2(207.7,226.6)$ & $39.0(36.7,41.3)$ & $284.8(247.5,322.0)$ \\
\hline \multirow[t]{2}{*}{ Abdominal Obesity ${ }^{\infty}$} & No & $198.1 \quad(192.4,203.9)$ & $38.3(36.5,40.0)$ & $190.3(175.1,205.6)$ \\
\hline & Yes & $207.6(\mid 98.0,217.1)$ & $37.7(35.2,40.2)$ & $253.3(216.5,290.8)$ \\
\hline \multirow[t]{4}{*}{ Region } & North & $201.4(191.0,211.8)$ & $36.6(33.8,39.4)$ & $193.0(158.9,227.1)$ \\
\hline & Central & 205.9 (I97.I,2।4.7) & $40.3(37.7,42.8)$ & $205.5(185.5,225.6)$ \\
\hline & Mexico city & - & - & - \\
\hline & South & $187.0(179.8,194.3)$ & $35.8(33.5,38.0)$ & $195.6(166.8,224.5)$ \\
\hline \multirow[t]{2}{*}{ Area } & Rural & $194.6(\mid 85.7,203.4)$ & $38.4(35.7,4 \mathrm{I} . \mathrm{I})$ & $198.8(\mid 76.4,221.3)$ \\
\hline & Urban & $204.6(|97.8,2| I .4)$ & $38.1 \quad(36.4,39.9)$ & $204.1 \quad(185.0,223.3)$ \\
\hline \multicolumn{5}{|c|}{ 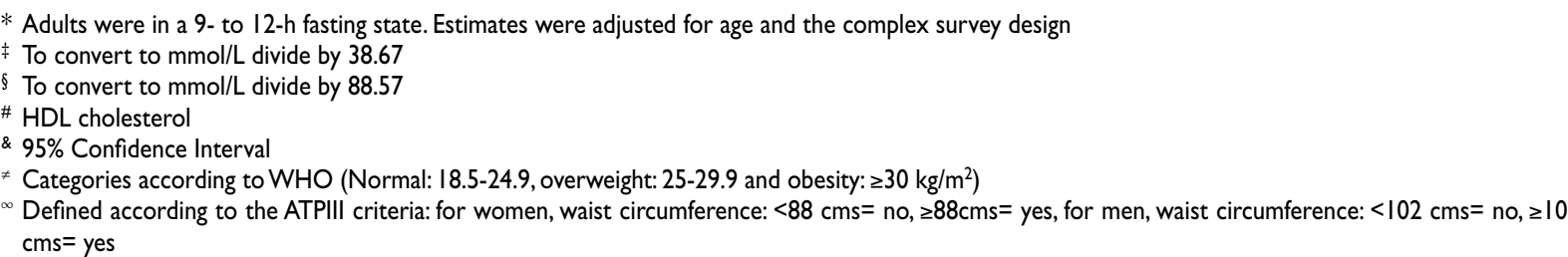 } \\
\hline
\end{tabular}

determinant of serum total cholesterol and the trend in Mexico is contrary to the one in the US where a decrease in fat consumption has been observed as well as a reduction of cardiovascular mortality. ${ }^{27,28}$ If fat consumption remains with a similar trend in Mexico, it is likely that the prevalence of hypercholesterolemia will increase in the next years. Cholesterol-lowering medications have been identified as a potential important factor for the reduction of cholesterol levels in the US. In Mexico, only $\sim 6 \%$ of the population acknowledged to have a previous medical diagnose of this condition. Thus, pharmacological treatment is not likely to be a factor producing effects at the population level at this time. As has been concluded from earlier studies, hypoalphalipoprotein- 
Table III

Prevalence of diverse lipid abnormalities in Mexican adults by age group, regions and strata, body mass INDEX AND abdominal obesity Category*. MeXican Health Survey, 2000

\begin{tabular}{|c|c|c|c|c|c|c|}
\hline & & $\begin{array}{l}\text { Cholesterol > 200mg/d } \\
\begin{array}{c}(>5.2 \mathrm{mmol} / \mathrm{L}) \\
\%(95 \% \mathrm{Cl})^{\mathrm{Q}}\end{array}\end{array}$ & $\begin{array}{c}H D L-c^{\ddagger}<40 \mathrm{mg} / \mathrm{dl} \\
(<1.0 \mathrm{mmol} / \mathrm{L}) \\
\%(95 \% \mathrm{Cl})^{8}\end{array}$ & $\begin{array}{c}\text { Triglycerides }>150 \mathrm{mg} / \mathrm{dl} \\
(>1.7 \mathrm{mmol} / \mathrm{L}) \\
\%(95 \% \mathrm{Cl})^{8}\end{array}$ & $\begin{array}{c}\text { Hypertriglyceridemia with hypo } \\
\text { a-lipoproteinemia } \\
\%(95 \% C l)^{8}\end{array}$ & $\begin{array}{c}\text { Mixed dyslipidemias \# } \\
\%(95 \% \mathrm{Cl})^{\mathrm{\alpha}}\end{array}$ \\
\hline Females & Total $(\geq 20 y)$ & $40.5 \quad(35.5,45.4)$ & $64.7(58.7,70.8)$ & $45.0 \quad(40.4,49.6)$ & $8.3(6.3,10.4)$ & $7.9 \quad(5.6,10.3)$ \\
\hline \multirow[t]{5}{*}{ Age group } & $20-29$ & $22.1 \quad(I 5.8,28.4)$ & $75.7 \quad(67.8,83.5)$ & $30.4 \quad(24.2,36.6)$ & $7.1 \quad(4.0,10.2)$ & $3.8 \quad(0.0,7.6)$ \\
\hline & $30-39$ & $43.4 \quad(35.9,50.9)$ & $65.6 \quad(57.5,73.8)$ & $49.9 \quad(42.0,57.8)$ & $12.3(7.2,17.3)$ & $4.7 \quad(2.0,7.4)$ \\
\hline & $40-49$ & $58.6 \quad(48.4,68.9)$ & $62.9 \quad(53.4,72.4)$ & $51.7 \quad(41.0,62.4)$ & 6.I $(2.5,9.7)$ & II.7 $(4.5,18.8)$ \\
\hline & $50-59$ & $64.6 \quad(52.7,76.5)$ & $43.0(30.3,55.6)$ & $73.9 \quad(64.5,83.3)$ & $12.2(4.9,19.6)$ & $22.5 \quad(7.0,37.9)$ \\
\hline & $\geq 60$ & $69.2 \quad(57 . I, 8 I .3)$ & $34.7 \quad(22.8,46.7)$ & $65.2 \quad(52.5,77.8)$ & $5.9(1.1,10.8)$ & $23.2(12.6,33.8)$ \\
\hline \multirow[t]{4}{*}{ Region } & North & $39.6(26.3,52.9)$ & $72.9 \quad(60.4,85.4)$ & $34.8 \quad(23.5,46.0)$ & $8.2(3.7,12.8)$ & $(2.6,13.5)$ \\
\hline & Central & $42.4 \quad(34.8,50.0)$ & $58.3 \quad(49.5,67.1)$ & $47.0 \quad(40.0,54.0)$ & $6 \quad(3.8,8.2)$ & $(5,12.5)$ \\
\hline & Mexico City & $53.5 \quad(9.7,97.3)$ & $66.4 \quad(3.9,128.8)$ & $19.9 \quad(1.2,38.5)$ & - & - \\
\hline & South & $36.2(29.3,43.1)$ & $72.7 \quad(63.9,81.5)$ & $44.4 \quad(37.9,50.8)$ & $12.5(8.0,17.1)$ & $6.5 \quad(3.5,9.6)$ \\
\hline \multirow[t]{2}{*}{ Area } & Rural & $41.9 \quad(33.5,50.3)$ & $63.1 \quad(54.0,72.3)$ & $50.9 \quad(43.7,58.1)$ & $8.6(5.7, \mid 1.5)$ & $9.3 \quad(5.4,13.1)$ \\
\hline & Urban & $39.1 \quad(33.8,44.4)$ & $66.3 \quad(58.4,74.1)$ & $39.4 \quad(34,44.8)$ & $8.1 \quad(5.1, I I . I)$ & $6.7 \quad(4.0,9.4)$ \\
\hline Males & Total $(\geq 20 y)$ & $44.6 \quad(37.7,51.4)$ & $61.4 \quad(54.5,68.3)$ & $53.5 \quad(47.2,59.8)$ & $12.9(8.9,17)$ & I4.4 (I0.4, I8.4) \\
\hline \multirow[t]{5}{*}{ Age group } & $20-29$ & $30.2 \quad(19.9,40.4)$ & $72.2 \quad(62.3,82.0)$ & $39.0(29.9,48.1)$ & $8.2(2.1,14.3)$ & $8.5 \quad(3.2,13.9)$ \\
\hline & $30-39$ & $52.5 \quad(39.6,65.4)$ & $49.8 \quad(37.7,61.8)$ & $67.1 \quad(55.8,78.5)$ & $20.4(10.0,30.9)$ & $(8.4,27.5)$ \\
\hline & $40-49$ & $67.3 \quad(55.1,79.5)$ & $52.1 \quad(37.3,66.8)$ & $63.3 \quad(48.4,78.2)$ & I3.0 (4.0,22.I) & $27.7(|14.0,4| .3)$ \\
\hline & $50-59$ & $61.2 \quad(44.6,77.7)$ & $49.1 \quad(31.0,67.1)$ & $74.5 \quad(61.3,87.8)$ & I3.2 $(3.4,23.0)$ & $19.3 \quad(7.6,31.1)$ \\
\hline & $\geq 60$ & $52.6 \quad(39.3,66.0)$ & $57.0(43.4,70.6)$ & $65.8 \quad(52.8,78.8)$ & $21.5(\mid 0.0,33.1)$ & II.I $\quad(3 . I, 19.2)$ \\
\hline \multirow[t]{4}{*}{ Region } & North & $39.5 \quad(28.5,50.4)$ & $74.9 \quad(65.4,84.4)$ & $44.0 \quad(31.9,56.0)$ & I6.I $(7.8,24.5)$ & $12.1(5.1,19)$ \\
\hline & Central & $53.8 \quad(43.0,64.5)$ & $49.6 \quad(39.4,59.7)$ & $59.8 \quad(50.6,69.1)$ & $10.1 \quad(4.1,16.1)$ & I7.2(II.3,23.I) \\
\hline & Mexico City & - & - & - & - & - \\
\hline & South & $30.5 \quad(20.9,40.1)$ & $74.7 \quad(64.9,84.6)$ & $45.9 \quad(36.8,55.0)$ & I5.3 (8.1,22.6) & II.2 (3.1,19.3) \\
\hline \multirow[t]{2}{*}{ Area } & Rural & $43.9 \quad(32.7,55.1)$ & $59.2 \quad(48.2,70.2)$ & $55.0 \quad(45.0,65.0)$ & I4.5 (7.7,2।.4) & $11.5 \quad(6.8,16.1)$ \\
\hline & Urban & $45.2(37.4,53.0)$ & $63.7 \quad(56.0,71.5)$ & $51.9 \quad(44.6,59.2)$ & II.2 (7.I,I5.3) & I7.5 $(10.8,24.3)$ \\
\hline
\end{tabular}

emia is the most frequent lipid abnormality, followed by hypertriglyceridemia in Mexican adults ${ }^{10}$ and other Latin-American populations ${ }^{29}$ Concentrations of HDLc $<40 \mathrm{mg} / \mathrm{dl}$ are considered a cardiovascular risk factor; ${ }^{17}$ in Mexico, the prevalence of this condition was $>60 \%$ for males and females, and $>70 \%$ for adults of $20-29-y$ of age, and adults living in the north and south country regions. The estimated probability for low HDLc without other lipid abnormalities was higher in normal than obese adults, suggesting a genetic component for this condition (Figure 1). We did not observe important differences of HDLc concentrations by sex as previously described in Mexico and other countries. Although we found a higher mean HDLc concentration in females, it was not significantly different from males. Further studies, such as the new Mexican Health and Nutrition survey currently in analysis, will be necessary to clarify this relationship in Mexico, since the number of cases was limited by the fasting condition reducing the power to detect differences. Information regarding 
Table IV

Adjusted Prevalence Ratios for diverse lipid abnormalities by body mass index AND WAIST CIRCUMFERENCE CATEGORY*

\begin{tabular}{|c|c|c|c|c|}
\hline $\begin{array}{l}\text { olesterol }>200 \mathrm{mg} / \mathrm{dl} \\
(>5 . I \mathrm{mmol} / \mathrm{L}) \\
\text { PR }(95 \% \mathrm{Cl})^{\&}\end{array}$ & $\begin{array}{c}H D L-c^{\ddagger}<40 \mathrm{mg} / \mathrm{dl} \\
(<1.0 \mathrm{mmol} / \mathrm{L}) \\
\operatorname{PR}(95 \% \mathrm{Cl})^{\mathrm{a}}\end{array}$ & $\begin{array}{l}\text { riglycerides }>150 \mathrm{mg} / \mathrm{dl} \\
(>1.7 \mathrm{mmol} / \mathrm{L}) \\
\operatorname{PR}(95 \% \mathrm{Cl})^{8}\end{array}$ & $\begin{array}{c}\text { Hypertriglyceridemia with hypo } \\
\text { a-lipoproteinemia } \\
\text { PR }(95 \% C l)^{\&}\end{array}$ & $\begin{array}{c}\text { Mixed dyslipidemias } \# \\
\text { PR }(95 \% C l)^{2}\end{array}$ \\
\hline
\end{tabular}

Females

\begin{tabular}{|c|c|c|c|c|c|c|}
\hline Body Mass Index & Normal $^{*}$ & 1.00 & I & 1 & I & I \\
\hline & Overweight & $\mathrm{I} .14(0.86, \mathrm{I} .44)$ & $1.02(0.84, I .18)$ & $1.41(1.07, I .74)$ & $1.74(0.95,3.07)$ & $0.79(0.24,2.3)$ \\
\hline & Obese & $1.40(1.05,1.74)$ & $1.09(0.91,1.25)$ & $1.44(1.10,1.76)$ & $1.69(0.89,3.06)$ & I.5 $(0.52,3.8 I)$ \\
\hline & $p$-value ${ }^{\infty}$ & 0.25 & 0.31 & $<0.01$ & 0.07 & 0.41 \\
\hline \multirow[t]{3}{*}{ Abdominal Obesity } & $\mathrm{No}^{\neq}$ & 1.00 & I & I & I & \\
\hline & Yes & $1.45(1.14,1.78)$ & $1.03(0.87,1.16)$ & I.8I $(1.44,2.16)$ & I.7I $(0.93,3.01)$ & $2.24(0.66,6.6)$ \\
\hline & $p$-value ${ }^{\infty}$ & $<0.01$ & 0.66 & $<0.01$ & 0.08 & 0.19 \\
\hline
\end{tabular}

Males

\begin{tabular}{|c|c|c|c|c|c|c|}
\hline Body Mass Index ${ }^{\varnothing}$ & Normal $^{\neq}$ & 1.00 & I & I & I & I \\
\hline & Overweight & $1.5 \quad(1.11,1.86)$ & $0.88(0.65,1.08)$ & $1.36(1.02,1.65)$ & I.6 $(0.66,3.4 I)$ & $4.06(2.04,7.24)$ \\
\hline & Obese & $1.93(1.54,2.24)$ & $0.84(0.63,1.04)$ & $1.78(1.48,1.97)$ & $2.02(0.86,4.07)$ & $5.25(2.48,9.42)$ \\
\hline & $p$-value ${ }^{\infty}$ & $<0.01$ & 0.11 & $<0.01$ & .09 & $<.01$ \\
\hline
\end{tabular}

\begin{tabular}{clllllll} 
Abdominal Obesity & $\mathrm{No}^{\neq}$ & $\mathrm{I} .00$ & $\mathrm{I}$ & $\mathrm{I}$ & $\mathrm{I}$ & $\mathrm{I}$ \\
\hline & Yes & $\mathrm{I} .19(0.87, \mathrm{I} .49)$ & $\mathrm{I}$ & $(0.7, \mathrm{I} .25)$ & $\mathrm{I} .44(\mathrm{I} .20, \mathrm{I} .62)$ & $\mathrm{I}) \mathrm{I5}(0.64, \mathrm{I} .96)$ & $\mathrm{I}) 27(0.67,2.22)$ \\
\hline p-value $^{\infty}$ & 0.23 & 0.99 & $<0.01$ & $0.6 \mathrm{I}$ & 0.45
\end{tabular}

* Adults were in a 9- to 12-h fasting state. Estimates were adjusted for: age, sex, socio-economic status, tobacco consumption and for the complex survey design

‡ HDL cholesterol

$\S$ Defined as: triglycerides $\geq 200 \mathrm{mg} / \mathrm{dl}(2.26 \mathrm{mmol} / \mathrm{L})$ and $\mathrm{HDL}$ cholesterol $<35(0.9 \mathrm{mmol} / \mathrm{L})$

\# Defined as: triglycerides $\geq 200 \mathrm{mg} / \mathrm{dl}(2.26 \mathrm{mmol} / \mathrm{L})$ and cholesterol $\geq 240 \mathrm{mg} / \mathrm{dl}(6.31 \mathrm{mmol} / \mathrm{L})$

\& $95 \%$ Confidence Interval

${ }^{*}$ Reference category

${ }^{\infty} \mathrm{p}$-value for the test for trend

- Categories according to WHO (Normal: 18.5-24.9, overweight: $25-29.9$ and obesity: $\geq 30 \mathrm{~kg} / \mathrm{m}^{2}$ )

Defined according to the ATPIII criteria: for women, waist circumference: $<88 \mathrm{~cm}=$ no, $\geq 88 \mathrm{~cm}=$ yes, for men, waist circumference: $<102 \mathrm{~cm}=$ no, $\geq 102 \mathrm{~cm}=y e s$

physical activity was not collected in this survey so we were unable to evaluate the contribution of this lifestyle condition to the HDLc levels in Mexican population. In Mexico, as in the US and other countries, obesity has been increasing in children and adults, ${ }^{1,22,26,30}$ this is a known factor associated with cardiovascular risk. In our study, obese adults were more likely to have hypertriglyceridemia and hypercholesterolemia than adults of normal BMI. In addition, obese adults were four times more likely to have three lipid abnormalities in comparison with normal BMI adults ( $p=0.16$ vs $p=0.04$ ) (figure 1). Thus, if the increasing trend in obesity persists; the coexistence of multiple dyslipidemias could become more prevalent in the next years. A clear relationship was observed between BMI categories (in males) and central adiposity (in females) for hypertriglyceridemia. Thus, the lipid profiles of obese and non-obese populations have relevant differences with the consequent associated risks.

Regions showed no significant differences, contrary to what has been previously reported. ${ }^{9}$ This is consistent with the regional catch-up phenomenon observed for NCCD mortality ${ }^{19}$ and to fat consumption patterns. ${ }^{31}$ In both examples the less developed south region had lower levels of mortality and fat consumption compared to the north region during the $80 \mathrm{~s}$; but recently a more homogeneous pattern across regions is observed, explained by greater changes in the south region. These changes may be related to the experienced shift in lifestyles with reduction of physical activity, and a diet with increasing 

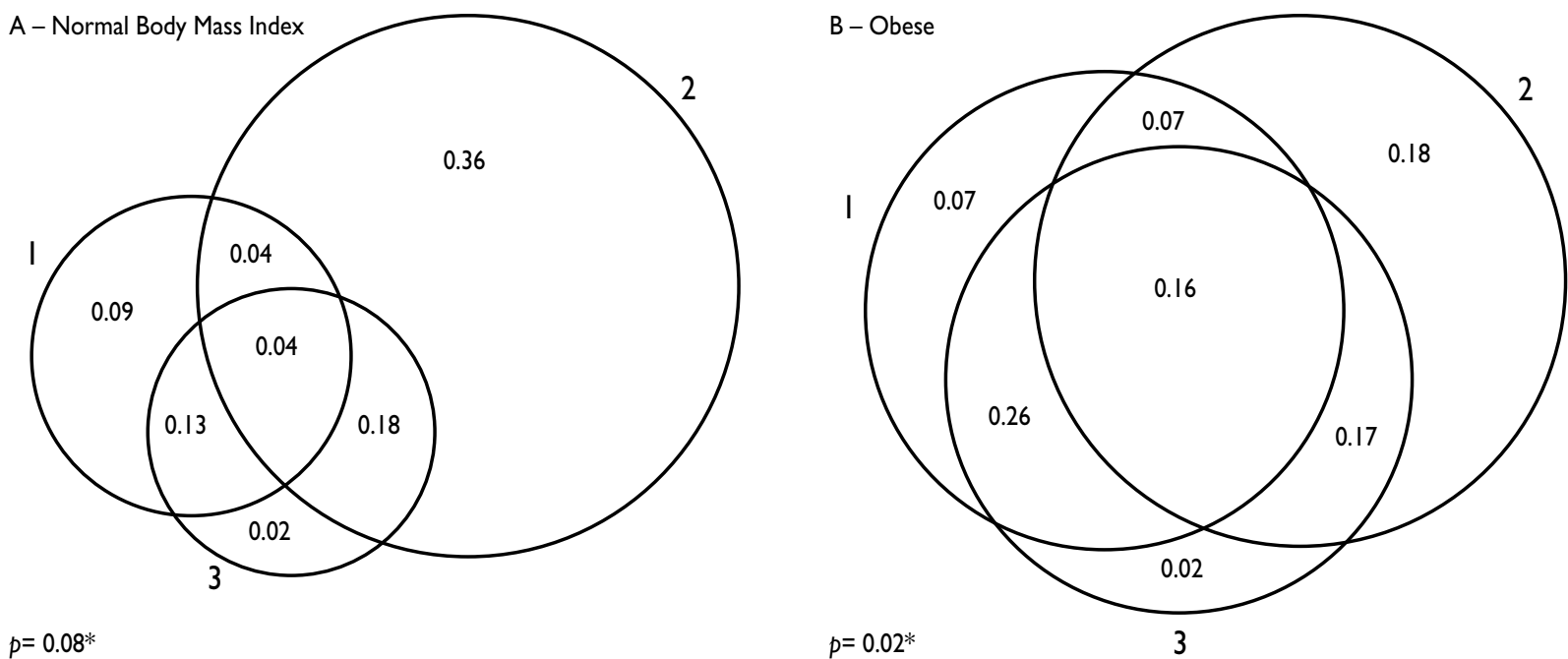

$p=0.08^{*}$

$p=0.02^{*}$

Adjusted for age and sex.A. Normal weight cases $\left(18.5-25 \mathrm{~kg} / \mathrm{m}^{2}\right)$, B. Obesity cases $\left(>30 \mathrm{~kg} / \mathrm{m}^{2}\right)$

$\mathrm{I}=$ Hypercholesterolemia (total cholesterol $>200 \mathrm{mg} / \mathrm{dl}$ )

$2=$ Hypoalphalipoproteinemia $(\mathrm{HDLc}<40 \mathrm{mg} / \mathrm{dl})$

$3=$ Hypertriglyceridemia (triglycerides $>150 \mathrm{mg} / \mathrm{dl}$ )

* Probability without any dyslipidemia

Figure I. Overlap between the probability of diverse lipid abnormalities in Mexican adults*

availability of fast and ready-to-eat foods (traditional and non-traditional), as well as consumption of processed foods rich in partially-saturated fat. 2,32

This information is consistent with diverse reports of lipid profiles in Mexican and Mexican-Americans. In contrast with the MCDS (1994) this information included subjects living in rural areas; however, differences between urban and rural population were not significant. One possibility is that adults living in rural areas have modified their life-styles to have a similar lipid profile than urban adults in recent times.

Lipid abnormalities are a major cardiovascular risk factor. Although ethnic differences in the lipid profile have been described; an environmental influence on the trends has been observed in Mexico and is likely to have a major role. The relative increase in the mortality rate for acute myocardial infarction and diabetes mellitus was $>50 \%$ during the $1980-2000$ period, which is an indicator of the burden of disease that is occurring in this nutrition and epidemiologic transition. ${ }^{1}$ Since our data were obtained from the individuals at fasting state during the survey and represented less than $6 \%$ of the total participants, the external validity of the study could be compromised. Some stratification such as by region could have limited the power to detect significant dif- ferences. Thus, this information needs to be confirmed by nationally representative data from new surveys.

Sound commitment from government authorities, participation from the society, promotion and education about healthy lifestyles, improved training of doctors and health professionals, and responsibility and commitment from the food and pharmacological industries are only some of areas of opportunity for improvement that could have an impact on this public health problem. ${ }^{33}$

\section{Acknowledgments}

This study was possible thanks to the Mexican National Council of Science and Technology (CONACyT) grant number 37194-M (Barquera S, Olaiz G, Villalpando S, Rivera J, González C, Sepúlveda J. Contribution of overweight and obesity to the development of risk factors for chronic diseases: analysis of the National Health Survey). We would like to acknowledge the assistance of Ricardo Robledo, PhD who implemented the techniques for the biochemical determinations. In addition we would like to thank Ismael Campos, MD, MS, Citlali Carrión, MS and Juan Espinosa, MS for their valuable assistance during the data analysis process, 
Carlos Aguilar-Salinas MD, for his input in the selection of cutoff points and interpretation of results and Richard Cooper MD, for his valuable comments to an earlier draft of this report.

\section{References}

I. Rivera-Dommarco J, Barquera S, Campirano F, Campos-Nonato I, Safdie M,Tovar V.The Epidemiological and Nutritional Transition in Mexico: rapid increase of non-communicable chronic diseases and obesity. Public Health Nutrition 2002; 14(44): I I3-122.

2. Drewnowski A, Popkin BM.The nutrition transition: new trends in the global diet. [Review] [57 refs]. Nutrition Reviews 1997;55(2):31-43. 3. Programa Nacional de Salud 200I-2006. México, DF: Secretaría de Salud, 2001.

4. Castelli W, Garrison R, Wilson P,Abbott R, LKalousdian S, Kannel W. Incidence of coronary heart disease and lipoprotein cholesterol levels. The Framingham Study. JAMA 1986;256(20):2835-2838.

5. Gordon D, Knoke J, Probstfield J, Superko R, HA.T. High-

density lipoprotein cholesterol and coronary heart disease in hypercholesterolemic men: the Lipid Research Clinics Coronary Primary Prevention Trial. Circulation 1986;74(6): I217-I225.

6. Escobedo J, Escamilla-Cejudo J, Santos-Burgoa C. Colesterol sérico y diabetes mellitus: principales factores de riesgo independientes en la mortalidad por cardiopatía isquémica en México. Arch Inst Cardiol Mex 1994;64:189-195

7. Sistema Nacional de Información en Salud. Principales causas de mortalidad general, 2003. México DF: Secretaría de Salud, 2005.

8. Tapia-Conyer R, Gutiérrez G, Sepúlveda J. Metodología de la Encuesta Nacional Seroepidemiológica, México. Salud Publica Mex 1992;34:124-135.

9. Posadas-Romero C, Tapia-Conyer R, Lerman-Gaber I, et al. Cholesterol levels and prevalence of hypercholesterolemia in a Mexican adult population.Atherosclerosis 1995; I 18:275-284.

10. Aguilar-Salinas CA, Olaiz G,Valles V, et al. High prevalence of low $\mathrm{HDL}$ cholesterol concentrations and mixed hyperlipidemia in a Mexican nationwide survey.J Lipid Res 200 I;42:1298-I307.

II. Posadas-Romero C, Sepúlveda J, Tapia-Conyer R, Magos C, CardosoSaldaña G, Zamora-González J.Valores de colesterol sérico en la población mexicana. Salud Publica Mex 1992;34:I57-167.

12. Gonzalez C, Stern M,Valdez R, Brazton M, Haffner H. Niveles de lípidos sanguíneos y riesgo aterogénico en población abierta urbana. Rev Inv Clin 1993;45: 127-132

13.Valles V,Aguilar-Salinas C, Gómez-Pérez FJ, et al. Apolipoprotein B and $A-I$ distribution in the Mexican urban adults: results of a nationwide survey. Metabolism 2002;5I(5):560-568.

14. Olaiz G, Rojas R, Barquera S, et al. Encuesta Nacional de Salud 2000.

Tomo 2. La salud de los adultos. Cuernavaca, Mor: Instituto Nacional de Salud Pública, 2003.

15. Barquera S, Carrión MC, Campos I, Espinosa J, Rivera JA, Olaiz G. Methodology of the fasting sub-sample from the Mexican Health Survey, 2000. Salud Publica Mex 2007;49:S420-S425.

16. Ley de Información Estadística y Geográfica. Diario Oficial de la Federación, Estados Unidos Mexicanos. 1980.
17. Expert panel on detection evaluation and treatment of high blood cholesterol in adults. Executive summary of the third report of the national cholesterol education program (NCEP) expert panel on detection, evaluation and treatment of high blood cholesterol in adults (adult treatment panel III). JAMA 200I;287:356-359.

18.WHO. Physical status: the use and interpretation of anthropometry. Geneva:World Health Organization, 1995.

19. Barquera S, Tovar-Guzmán V, Campos-Nonato I, GonzálezVillalpando C, Rivera-Dommarco J. Geography of diabetes mellitus mortality in Mexico: an epidemiologic transition analysis. Arch Med Res 2003;34(5):407-4I4.

20. Hernandez-Diaz S, Peterson K, Dixit S, et al.Association of maternal short stature with stunting in Mexican children: common genes vs common environment. Eur J Clin Nutr 1999;53:938-945.

21. Zhang J,Yu KF.What's the relative risk? A method of correcting the odds ratio in cohort studies of common outcomes. JAMA 1998;280(19):1690-1691.

22. Must A, Spadano J, Coakley EH, Field AE, Colditz G, Dietz WH. The disease burden associated with overweight and obesity. Jama 1999;282(16):1523-1529.

23. Chow S, Ruskey F. Drawing area-proportional Venn and Euler diagrams. Proc Graph Drawing 2004;2912:466-477.

24. Carroll MD, Lacher DA, Sorlie PD, et al. Trends in serum lipids and lipoproteins of adults, 1960-2002. Jama 2005;294(I4): I773- I78I.

25. Ford E, Mokdad A, Giles W, Mensah G. Serum total cholesterol concentrations and awareness, treatment, and control of hypercholesterolemia among US adults. Findings from the National Health and Nutrition Examination Survey, 1999 to 2000. Circulation 2003;107:2185-2189.

26. Rivera J, Barquera S, Gonzalez-Cossio T, Olaiz G, Sepulveda J. Nutrition transition in Mexico and other Latin American countries. Nutrition Reviews 2004;62(7):SI-S9.

27. Cooper R, Cutler J, Desvigne-Nickens P, et al. Trends and disparities in coronary heart disease, stroke, and other cardiovascular diseases in the United States: findings of the national conference on cardiovascular disease prevention. Circulation 2000;102(25):3137-3147.

28. Cooper R, Stamler J, Dyer A, Garside D. The decline in mortality from coronary heart disease, USA, 1968-1975.J Chronic Dis 1978;3I(I2): 709-720.

29. Florez $\mathrm{H}$, Silva $\mathrm{E}$, Fernández $\mathrm{V}$, et al. Prevalence and risk factors associated with the metabolic syndrome and dyslipidemia in White, Black, Amerindian and mixed Hispanics in Zulia state,Venezuela. Diabetes Res Clin Pract 2005;69:63-77.

30. Smith S, Clark L, Cooper R, et al. Discovering the full spectrum of cardiovascular disease. Minority Health Summit 2003. Report of the obesity, metabolic syndrome and hypertension writing group. Circulation 2005; I I :el34-el39.

31. Barquera S, Hotz C, Rivera J, et al. Food consumption, food expenditure, anthropometric status and nutrition related diseases in Mexico. Nutrition and the double-burden of disease in developing countries. Rome: Food and Agricultural Organization (FAO), 2006:161-257. 32. Drewnowski A, Popkin BM. The nutrition transition: new trends in the global diet. Nutrition Reviews 1997;55(2):31-43.

33. Epping-Jordan J, Pruitt S, Wagner E. Improving the quality of health care for chronic conditions. Qual Saf Health Care 2004;13:299-305. 